\title{
Joining the mice-eyed decipherers
}

In July 1929, at the height of the Jazz Age and two months shy of his twenty-third birthday, William Empson was rusticated by Magdalene College - indeed, banished from Cambridge town having been discovered in possession of prophylactics and/or engaged in sex with a woman. ${ }^{1}$ But randy William had already composed and would shortly publish Seven Types of Ambiguity, which, alongside The Meaning of Meaning produced by his tutor I. A. Richards and collaborator C. K. Ogden, became foundational texts of the 'New Criticism', modern literary theory, semiotics, and the practice we know as 'close reading'. Ever since, literary scholars have parsed, deconstructed, interrogated, and endlessly re-interpreted passages of prose and poetry in a relentless quest for meaning, secondary (and tertiary) meanings, allusions, topicalities, metadramatic substrate, and authorial intentions (and tenure). By this declension, many have come to regard close reading as a modern innovation. It isn't. Subjecting a text to intensive scrutiny in order to discover recondite referents, insinuations, and/or connotations is hardly a new-found pastime. Close readers were the bugbears of writers of plays, prose and poetry during William Shakespeare's working lifetime as likely they were in Chaucer's and Euripides'. There is ample evidence, including vociferous complaints by Shakespeare's colleagues, their prosecutions and jailings, that their literary productions were closely audited and read, parsed, analysed, sifted to a fare-thee-well, curiously interpreted, and frequently misconstrued.

Elizabethan readers and auditors wished to come to grips with not only what their authors wrote, but what they thought - and that included not only what they said, but what they said they didn't say but did. Shakespeare and his colleagues were confronted by 
an avid but dissimilarly lettered public hungry for entertainment, information, and enlightenment and fully committed not only to hearing and reading their authors' texts, but to reading their minds. Below I'll reiterate furious protests against close reading by some of Shakespeare's writer-contemporaries. But bear in mind: Elizabethan authors were shrewd enough to recognize that protesting their innocence would only amplify the public's appetite for closely reading their works. Then as now, controversy made excellent publicity.

In his lifetime, Shakespeare was wise enough to avoid such growling; he never claimed that what wasn't there wasn't there, even when it wasn't. But his fellow actors and first editors, John Heminges and Henry Condell, demanded that we read between his lines. In the forepages of the First Folio they encouraged 'the great Variety of Readers' to

Reade him, therefore; and againe, and againe: And if then you doe not like him, surely you are in some manifest danger not to understand him. And so we leave you to other of his Friends, whom if you need, can bee your guides: if you neede them not, you can leade your selves, and others. And such Readers we wish him. ${ }^{2}$

When Heminges and Condell published these words Shakespeare was seven years in his grave and safely beyond the innuendos - but not the ken - of those whom Thomas Nashe had challenged as 'mice-eyed decipherers'.

During his life Shakespeare had been sufficiently wise to recognize that authorial disclaimers and protests of innocence would only excite notoriety and invite closer scrutiny. In fact, we seem to have only one repudiation from his lips - and that a markedly mild one, hardly more than a brushstroke - when he muttered in the Epilogue of 2 Henry IV, 'Oldcastle died martyr, And this is not the man' (Epi. 31-2).

Heminges and Condell declared that post mortem was high time to search Shakespeare's pockets, and that is exactly what I intend to do.

\section{Close reading in a time of censorship}

Among the Elizabethan public's motives for indulging in close reading - which as today ranged from curiosity to gossipmongering to scholarly interest to prurience - one of the most 
tantalizing was their awareness of England's rigorous censorship of unofficial discourse on politics, the royal succession, foreign relations, religion, and certain personalities. Elizabethan England was a highly censorious arena, and dangerous for writers - playwrights particularly - who openly flaunted topicality. As Annabel Patterson notes in Censorship and Interpretation, 'governments fear the theater more than other forms of literature because of its capacity to stir up public opinion' 3 - presumably because books and other documents tend to be read in private, and the reader's opinion is, therefore, privately formed, whereas the experience of a play is shared with hundreds or thousands of spectators whose response to ideas laid before them is immediately detectable as 'the sense of the house'.

In one instructive act of censorship, on 12 November 1589 the Privy Council ordered the Archbishop of Canterbury, the Lord Mayor of London, and the Master of the Revels to

consider of the matters of their the playing companies' comedyes and tragedyes, and thereuppon to strike oute or reform such partes and matters as they shall fynd unfytt and undecent to be handled in playes, bothe for Divinitie and State, comaunding the said companies of players, in her Majesties name, that they forbear to present and playe publickly anie comedy or tragedy other then suche as they three shall have seene and allowed, which if they shall not observe ... they shalbe not onely sevearely punished, but made incapable of the exercise of their profession forever hereafter. ${ }^{4}$

Modern scholars who regard this tri-partite commission as a lacuna of beneficence are naïve. Crossing the censors' intentionally vague and purposely ill-defined touchlines could invite a book burning (Nashe, Harvey, Marlowe, et al.), imprisonment (Jonson, Hayward, et al.), mutilation (Stubbes, Page), or even silence and ruin (Lyly, Nashe, et al.). Professor Patterson characterizes these ground rules as the 'cultural code' which embodied the 'hermeneutics of censorship' in Tudor-Jacobean England. ${ }^{5}$ But the canons were sufficiently indistinct and the punishments sufficiently draconian to inspire prudence and self-censorship in any writer. ${ }^{6}$ Patterson contends that 'the occasional imprisonment, however arbitrary, had exemplary or ritual force'. ${ }^{7}$ Surely it was this arbitrary, even capricious, and therefore unpredictable enforcement which, as much as the severity of punishments, tended to snaffle writers. 
A particularly curious (and worrisome) instance was the burning of certain books which touched neither 'Divinitie' nor 'State', ordered and effected on 1-4 June 1599 by the Archbishop of Canterbury, John Whitgift, and the Bishop of London, Richard Bancroft. They decreed 'that all Nashe's bookes and Dr. Harvey's bookes be taken wheresoever they be found, and that none of the said bookes be ever printed hereafter'. The order banned the printing of histories without Privy Council authorization, and the printing of plays 'excepte they bee allowed by suche as have aucthorytie'. ${ }^{8}$ It is thought Nashe and Harvey were silenced as a consequence of the vitriolic pamphlet war they had waged since Richard Harvey's opening salvo in $1590 .^{9}$

But exactly why the pair were cited and received the ultimate punishment (silencing) has never been satisfactorily explained. Charles Nicholl believes that Nashe was cited as fons et origo of the flurry of satirical books (which he was not), and Harvey as co-respondent. ${ }^{10}$ But none of the transgressions proposed 'licentiousness', 'offence against morality', 'pornographic', 'sexual subjects', homosexuality - is wholly persuasive. ${ }^{11}$ (See 'Why the Bishops Burned the Books' in 'Longer notes' below for a more likely explanation.)

As the recent histories of Nazism and Stalinism spectacularly demonstrated, readers and audiences belaboured by a censorious regime are keen to read into any published or performed work an array of seditious propositions and arguments, concealed identities, innuendos, and insinuations. Such audiences are alert to any nuance, wink, hesitation, interpolation, or misquotation which might convey a political point. In Shakespeare's age this was equally true - and not only among auditors of so-called 'city plays' which engaged and dispatched the affectations and affectors of contemporary London society with tooth-edged, biting satire. Under the groaning of Elizabethan censorship, any play - any character - might be a carrack laden with contraband ideas and sentiments. Any scene or sub-plot might be an allegory masquerading as comedy.

This brings us to a critical point in our discussion: Elizabethan readers and playgoers had better memories than we do, and read books and attended plays with eyes and ears more keenly tuned to recognize secondary, esoteric, metaphorical, and otherwise veiled meanings. This is not easily grasped by modern citizens of free 
societies accustomed to forthright, uncensored modes of expression. In today's literature, cinema, and Internet entertainment, and in our print and electronic journalism, we expect bald, unmodulated frankness. Shakespeare's contemporaries didn't.

Unlike our unbuttoned society, Elizabethans knew there were rules against the staging of the sacraments or treating with matters of state. Playwrights who transgressed the latter prohibition - for example, Jonson and Nashe with The Isle of Dogges in 1597 wound up fined, jailed, or in self-imposed internal exile. Eventually, there were rules against profanity and taking the name of the Lord in vain (1606), which is perhaps why in the Folio As You Like It (1623) Rosalind uses the Latinate euphemism 'Jove' when calling for divine witness: 'Iove, Iove, this shepherd's passion Is much upon my fashion' (2.4.56). What we must recognize is that when Rosalind invoked 'Jove' Shakespeare's auditors heard 'God'.

For Shakespeare's first audiences, wringing recondite messages out of books and playtexts wasn't merely a pastime, it was a passion. In a sense, close reading was one of many word-games (such as anagrams) popular among lettered Elizabethans. They also encountered books and plays which openly drew on contemporary life and personalities, and presented them unmasked, unmuffled, and in the raw. When this occurred, the authorities could act quickly.

On 10 May 1601 the Privy Council complained to the Justices of the Peace of Middlesex

that certain players that use to recite their plays at the Curtain in Moorfields do represent upon the stage in their interludes the persons of gentlemen of good desert and quality that are yet alive under obscure manner, but yet in sort as all the hearers may take notice both of the matter and the persons that are meant thereby. ${ }^{12}$

The practice provoked a stern rebuke:

This being a thing very unfit, offensive, and contrary to such direction as have been heretofore taken that no plays should be openly showed but such as first were perused and allowed and that might minister to occasion of offense and scandal we do hereby require you that you do forthwith forbid ... them to from henceforth to play the same, either privately or publicly, and ... to take bond of the chiefest among them to answer their rash and indiscreet behavior before us. ${ }^{13}$

However, Arthur Kinney notes that living 'gentlemen could be played onstage if they were played favorably' and cites as evidence a 
letter from Rowland Whyte to Sir Robert Sidney dated 26 October 1599:

Two days ago, the overthrow of Turnhout was acted upon a stage, and all your names used that were at it; especially Sir Fra. Veres, and he that played that part got a beard resembling his, and a watcher Satin Doublet, with Hose trimmed with silver lace. You was [sic] also introduced, killing, slaying, and overthrowing the Spaniards, and honorable mention of your service, in seconding Sir Francis Vere, being engaged. ${ }^{14}$

Professor Kinney goes on to say, 'It is tempting to find contemporary originals for Sir Toby Belch or Sir Andrew Aguecheek (Twelfth Night), Osric (Hamlet) or Oswald (Lear), but the only evidence we now have indisputably is Shakespeare's satire of the deceased Sir John Oldcastle in 1 Henry IV. We still do not know why [the playwright risked doing that]. ${ }^{15}$ If we are asking ourselves such questions four hundred years after the fact, wasn't the buzz of speculation among Shakespeare's auditors during their après-théâtre suppers loud and sustained? If occasions were plentiful, as we may infer they were, when recognizable Elizabethans were portrayed on stage for better or worse, should that not compel us to sift carefully for Shakespeare's inspirations for his characters? His first auditors conditioned to see living persons portrayed on stage - did.

\section{Authors protest close reading}

Shakespeare's colleagues were not always flattered by the close attention paid to their texts. That could bring troubles unsought for. Thomas Nashe complained against close readers who (so he alleged) misinterpreted his works. In Strange Newes (1592), Nashe grumbled: 'Now a man may not talk [write] of a dog but it is surmised that he aims at him that giveth [exhibits] the dog in his crest [probably John Talbot, Ninth Earl of Shrewsbury, d. 1611]; he cannot name straw, but he must pluck a wheat-sheaf in pieces [probably Thomas Cecil, Earl of Exeter, 1542-1623].' Nashe caps his snarl at the impertinence of his misinterpreters, 'Intelligendo faciunt ut nihil intelligant' - they pretend understanding, but understand nothing. ${ }^{16}$

Nashe's indignation had not cooled when he produced Christ's Tears over Jerusalem (1593): 'I am informed there be certain busie wits abroad that seek to anagrammatize the name of Wittenberge 
to one of the Universities of England ... for not so much as out of mutton and pottage but they will construe a meaning of kings and princes. ${ }^{17}$ Devising anagrams was a favourite word-game of lettered Elizabethans - including Queen and courtiers - both as an amusement and recognized mode of esoteric discourse. I will show that Shakespeare played at anagrams to entertain the Queen in Twelfth Night.

Now Nashe locks horns with his most imaginative close readers:

Let one but name bread, they will interpret it to be the town of Bredan in the Low Countreyes; if of beere he talkes, then straight he mockes the countie Beroune in France; if of foule weather or a shower of raine, he hath relation to some that shall raign next. Infinite numbers of these fanatical strange hieroglyphics have these new decipherers framed to themselves, \& stretched words on the tenterhookes so miserably that a man were as goode, considering every circumstance, write on cheverel as on paper. For my part, I would wish them not to deceive themselves with the spirite of inspiration without proofe, or confound logic by making no difference betwixt probabile and manifeste verum. ${ }^{18}$

Nashe's 'probabile' = 'probable, likely' rather than 'possibile' = 'possible, perhaps' sharply undercuts his claims of innocence; it is either a slip of the pen or a provocation.

In Nashes Lenten Stuffe (1599) the satirist produced what may be his most conspicuous allegory. 'Ostensibly written as a panegyric to the city of Yarmouth and its chief product [herring], the work's rambling, stream-of-consciousness style soon yields to Nashe's legendary invective and devolves into a scathing critique of papists and court culture.' ${ }^{19}$ Nashe brazenly challenged close readers to solve the riddles of his relentlessly riddling Stuffe: 'O, for a Legion of mice-eyed decipherers and calculaters vppon characters, now to augurate what I mean by this: the diuell, if it stood vpon his saluation, cannot do it. ${ }^{20}$ By issuing this challenge - and writing 'probabile' rather than 'possibile' - wasn't Nashe asking (if not begging) for ever more close reading which could only enhance his reputation as a social scold?

Another contemporary critic of society, Ben Jonson (1572-1637), complained in his preface to Volpone, or The Fox that close reading

and (mis)interpretation of literary texts 'is now grown a Trade with many; and there are that profess to have a Key for the decyphering 
of every thing: But let Wise and Noble Persons take heed how they be too credulous, or give leave to these invading Interpreters ... who cunningly, and often, utter their own virulent Malice under other Mens simplest Meanings. ${ }^{21}$

Jonson decries these misinterpreters of minutiae who are

so solemnly ridiculous, as to search out who was meant by the gingerbreadwoman, who by the hobby-horse man, who by the costardmonger, nay, who by their wares ... what great lady by the pig-woman, what concealed statesman by the seller of mousetraps [and, thereby] challenge the author of scurrility, because the language somewhere savors of Smithfield. ${ }^{22}$

Though Jonson raised several strenuous denials, it was no secret that his plays gleefully savaged the foibles of contemporary Londoners. Indeed, Jonson finally admitted that many of his characters had been drawn from life; in his Apologetical Dialogue (1616) he confessed, 'Now for the players, it is true, I tax'd [censured] them' - referring to his Poetaster written, as he put it, 'on' Marston. ${ }^{23}$

But Jonson also defended his practice by claiming - and a curious claim it is - that he had sufficiently disguised his living models so that no 'narrow ey'd Decipherers' could say with certainty who his victims were. That is: the targets of Jonson's vitriole - the living persons behind his masks - are both sufficiently obscured to be unidentifiable and sufficiently obvious to be recognizable. This is at best paradoxical, at least sophistical. And Jonson issued a blanket challenge: 'What Nation, Society, or general Order or State I have provoked? What Publick Person? Whether I have not (in all these) preserv'd their Dignity, as mine own Person, safe? ${ }^{24}$ Just as in the case of Nashe, wouldn't such a disclaimer - such defiance - provoke even more close reading?

Jonson went so far as to depict the alternative to his brand of vigorous, topical satire as an unwelcome return to the days when the stage was peopled not with characters, but with personifications of Virtue, Vice, and Everyman. He castigated

those severe and wise Patriots, who providing [weighing] the Hurts these licentious Spirits [satirists] may do in a State, desire rather to see Fools and Devils, and those antick Relicks of Barbarism retrivd, with all other ridiculous and exploded Follies, than behold the Wounds of Private Men, of Princes and Nations. ${ }^{25}$ 
Jonson has offered his readers a prickly choice: either his genre of topical, satirical plays which lampoon the faults and transgressions of thinly veiled contemporaries - or a return to the desiccated Morality.

Clearly, the protestations of Nashe and Jonson could only inflame 'mice-eyed decipherers' and 'invading Interpreters' more finely to sift their works for topicalities and personalities. And they knew it. One can hardly ask for a more conclusive proof that Elizabethan literature was stuffed with topical, personal, cheeky, impertinent (and judgemental) portraits of living persons.

\section{How the mice-eyed empower writers}

More than a few years ago when I was in my salad days and bent on 'seeing the world', a Czech friend took me to a dingy club in Prague where a mob of dirty young people had assembled to listen to a dirty young band who played a brand of music we remember as 'garage rock' or 'garage punk' but that sounded like anarchy with a beat. One of their offerings was as dreary and downbeat as a dirge. In fact, it closed with a chant which can only be likened to Mongolian 'throat singing'. When it ended there was dead, absolute silence - as if the audience could not believe what they had heard. Then the room exploded with shouts and cheers, a mix of hysterical glee and seething rage. I didn't understand Czech. Even if I had, I don't think I could have grasped what I'd witnessed. Later, my host explained that the chant which so electrified the young Máničky ran:

konečně jsem dnes pane K. rozuměl psovi

konečně jsem dnes pane K. rozuměl psovi

konečně jsem dnes pane K. rozuměl psovi

Roughly translated, the words mean 'Finally, today I understood Mr. K's dog.' Why should this phrase repeated three times electrify a crowd of young Czechs?

Because they all knew they were living under a repressive Communist regime - which is why that band, Plastic People of the Universe, had been debarred from performing in public. Everyone in that cold basement shared the everyday experience of living in a dictatura. And many knew the text to which the song referred: Investigations of a Dog (1922) by Franz Kafka, in which a dog tries 
to understand by logic and 'science' the mysteries of life to which other dogs seem oblivious. Mr. K’s dog concludes:

It was this instinct that made me - and perhaps for the sake of science itself but a different science from that of today, an ultimate science that prized freedom higher than everything else. Freedom! Certainly such freedom as is possible today is a wretched business. But nevertheless freedom, nevertheless a possession. ${ }^{26}$

One couldn't deliver a more explicit protest against the repression of the Gierek regime. Kafka provided the 'touchstone' text - a text which, though absent, was alive in the minds of performers and auditors alike. For Shakespeare's auditors that touchstone text was often the Geneva Bible. ${ }^{27}$

It is difficult for scholars in a free society to grasp how a violent censorious regime raises the consciousness of citizens who read books and attend performances. Though authorities have the power to repress free expression, their efforts have a double effect: readers and auditors learn to attend more closely to what authors and performers say. They come prepared. And eager to seize on every hint, allusion, or intimation which might have a social or political connotation. Censorship creates better readers and listeners. And that empowers writers to say what everyone thinks without saying it.

That Shakespeare - like Nashe, Jonson, and every writer living or dead - drew characters from life is hardly debatable. But the intelligent search for life behind the masks of Shakespeare's characters has been perverted by the rantings of conspiracy theorists, self-styled code breakers, creationists, anti-vaccinationists, and monomaniacs determined to appropriate Shakespeare to their personal cause or prove him their co-religionist. As to whether there are skeletons in Shakespeare's plays to be unearthed by literary archaeology, there's bountiful evidence that he and his contemporary dramatists (like all writers since Genesis) modelled many of their characters on lovers, friends, and enemies. Frances Trollope (1799-1863), a writer and social critic before her time who skewered Americans' manners in 1823 and Parisians' in 1835, said of the way she constructed her characters, 'Of course, I draw from life - but I always pulp my acquaintances before serving them up. You would never recognize a pig in a sausage. ${ }^{28}$ 
In the following chapters I will hazard the wrath of Nashe and Jonson, and join the mice-eyed in raking for the identities of lovers, friends, enemies, and benefactors whom Shakespeare ground up, spiced up, and served up. Though long obscure to us, they may have been perfectly transparent to those readers and auditors whom Gabriel Harvey dubbed 'the wiser sort' - cognoscenti with a knack for picking the pig from the sausage. And I will begin with Shakespeare's most elaborate and dramatic portrait, drawn of a man he may have admired as colleague, friend, and mentor.

\section{Notes}

1 John Haffenden, William Empson, 2 vols (Oxford: Oxford University Press, 2005), I.242-7. Given that the offences alleged were of a sexual nature, and therefore a violation of University regulations, Empson 'could no longer reside within the town bounds' (243).

2 John Heminges and Henry Condell, eds, Shakespeare: The First Folio (London: Jaggard, 1623), A3r.

3 Annabel Patterson, Censorship and Interpretation (Madison: University of Wisconsin Press, 1984), 14.

4 Quoted in E. K. Chambers, The Elizabethan Stage, 4 vols (Oxford: Clarendon Press, 1923), IV.306-7.

5 Patterson, Censorship, $52 \mathrm{ff}$.

6 An egregious and instructive contemporary occasion of censorship is the law against 'gay propaganda' passed by the Russian Duma on 11 June 2013; while it provides for lengthy prison sentences and hefty fines, nowhere does it specify what constitutes illegal propaganda.

7 Patterson, Censorship, 13.

8 Edward Arber, A Transcript of the Registers of the Company of Stationers of London, 5 vols (London and Birmingham, 1875-94), III.677-8.

9 In his Theological Discourse of the Lamb of God (London, 1590), Richard Harvey had attacked Nashe by name.

10 Charles Nicholl, A Cup of News: The Life of Thomas Nashe (London: Routledge \& Kegan Paul, 1984). The eight other books burned were John Marston, The Metamorphosis of Pigmalions Image and Certaine Satyres and The scourge of vilanie (both London, 1598); Edward Guilpin, Skialetheia (London, 1598); Thomas Middleton, Microcynicon (London, 1598); John Davies, Epigrames and Elegies (London, n.d. [ca. 1599]), which included several of Marlowe's translations of Ovid's Amores; Ercole and Torquato Tasso, Of Marriage and Wyvinge (London, 1599) and The xv ioyes of marriage (London, 
n.d. [ca. 1598]); and Joseph Hall, Virgidemiarum, 2 vols (London, 1597-98). Scholars still debate why Caltha Poetarum (London, 1599) by 'Thomas Cutwode' (Tailboys Dymock, fl. 1584-1602) received a reprieve.

11 Charles Ripley Gillett, Burned Books: Neglected Chapters in English History and Literature, 2 vols (New York: Columbia University Press, 1932), I.90; Lynda Boose, 'The 1599 Bishops' Ban and Renaissance Pornography', in Richard Burt and John Michael Archer, eds, Enclosure Acts: Sexuality, Property, and Culture in Early Modern England (Ithaca, NY: Cornell University Press, 1994), 191-9; Bruce Smith, Homosexual Desire in Shakespeare's England (Chicago: University of Chicago Press, 1991, 2nd edition 1994), 165.

12 Glynne Wickham, Herbert Berry, and William Ingram, eds, Theatre in Europe: A Documentary History (Cambridge: Cambridge University Press, 2000), 414.

13 Ibid.

14 Arthur F. Kinney, Shakespeare by Stages: An Historical Introduction (Oxford: Blackwell Publishers, 2003), 149.

15 Ibid.

16 Ronald B. McKerrow, ed., The Workes of Thomas Nashe, 5 vols (London: Sidgwick \& Jackson, 1904-10, repr. Oxford: Basil Blackwell, 1958), I.261.

17 Alexander Bulloch Grosart, ed., The Complete Works of Thomas Nashe, 6 vols (London: privately printed, 1883-84), IV.5.

18 Ibid.

19 Henry S. Turner, 'Nashe's Red Herring: Epistemologies of the Commodity in Nashes Lenten Stuffe (1599)', English Literary History 68.3 (2001), 529-61.

20 Grosart, Nashe, III.218.

21 Ben Jonson, The Works of Ben Jonson (London: Hodgkin, 1692); Ben Jonson, Epistle to the two universities, Volpone; or, The Fox (London, 1605), 154.

22 Ben Jonson, Bartholomew Fair (London, 1605), 'The Induction', 374.

23 Jonson, Apologetical Dialogue (London, 1616), 128.

24 Jonson, Epistle, 153-4

25 Ibid.

26 Franz Kafka, The Complete Stories (New York: Schocken E-Books, 1971), 345.

27 Citations throughout are from The Geneva Bible (London, 1599).

28 ca. 1848. Sabine Baring-Gould, Early Reminiscences 1834-1864 (New York: Dutton, 1922), 128. 